\title{
From Slang to Acceptability: Style-Shifting Variation in English Language Usage by Students of CRUTECH, Calabar, Nigeria
}

\author{
Mercy Ugot \\ Centre for General Studies \\ Cross River University of Technology \\ P.M.B 1123, Calabar, Cross River State, Nigeria \\ E-mail: mercyugot@yahoo.com
}

Received: 01-10-2013

doi:10.7575/aiac.ijalel.v.3n.1p.231
Accepted: 03-12-2013

Published: 01-01-2014

URL: http://dx.doi.org/10.7575/aiac.ijalel.v.3n.1p.231

\begin{abstract}
This paper focuses on informal language usage by students of Cross River University of Technology, Calabar, Nigeria. This includes the use of slang words from primarily the substrate and superstrate language of the mother tongue (MT) and Nigerian Pidgin (NP) respectively. Participant observation was used for this work including lectures and other forums. Focus is on the speech discourse of students. The NP in particular is a contact language which has grown in stature due to factors of relevance as a common language in a pluralistic society like the Cross River State in particular, and Nigeria in general. Its use has also expanded due to urbanization. The MT has been observed to be influential through direct translation of certain expressions. Findings have shown that the informal use of language by the students has inadvertently affected their competence in standard and formal language use.
\end{abstract}

Keywords: Contact language, substrate, speech convergence, slang, style-shifting.

\section{Introduction}

All speeches occur in an interactive context in which interactants-speakers and hearers - make choices from the linguistic system. These include lexical and grammatical choices which express appropriate experiential meaning, that is, meaning concerned with the world of experience (Millar 2007)

A continuum of variation is precisely what one usually finds in social context related variation, which is sometimes, referred to as style-shifting (Singleton 2002). In all languages people adjust their language style according to the situation in which communication is taking place and according to the relationship that exists between the participants in the interaction. Secondly, the particular variety or varieties that we use are not imposed on us but rather reflect the models we adopt and attachment affiliations we enter into. Everyone will have been involved in what is usually called style-shifting, that is to say in making relatively subtle changes in the language we use in response to differences in context-adjusting. For example, with regard to the lexical aspects of style-shifting some expressions are relatively neutral in respect of the kinds of contexts in which they are likely to occur. Some are identifiable as unlikely to be used in formal circumstances, whilst others are unlikely to be associated with informal communication. The following examples as cited by Singleton (2000: 122) illustrates this for British English (BE)

$\begin{array}{lll}\text { Formal } & \text { Neutral } & \text { Informal } \\ \text { 1a) Diminutive } & \text { Small } & \text { Teeny-weeny } \\ \text { b) Garments } & \text { Clothes } & \text { Threads } \\ \text { c) Offspring } & \text { Child } & \text { Sprog } \\ \text { d) Voluminous } & \text { Large } & \text { Whopping } \\ \text { e) Weep } & \text { Cry } & \text { Blub }\end{array}$

In this paper, we shall focus on the use of slang by CRUTECH students as a style-shifting variation. This style-shifting variation is borne out of a need to communicate at a particular level in an environment where the preferred form of communication is one of formal language usage. This variation is also influenced by the fact that the university community is multilingual in nature.

\subsection{Literature Review}

Slang, according to Holmes (2008) is a somewhat imprecise term used for colloquial informal or non-standard language. An important motivation for language change is to establish and maintain group identity and cohesiveness on the one hand and to signal its distinctiveness from other groups on the other hand. Macgregor (2009) claims that youth and occupational groups often employ some lexical items peculiar to themselves, or give existing lexemes new senses. 
Youth slangs or jargons distinguish members from older people because they change so rapidly. But it is more than mere fashion that motivates such lexical changes: the fashion serves to distinguish group members from outsiders.

All language change has its origin in variation. The possibility of a linguistic change exists as soon as a new form develops and begins to be used alongside an existing form. If the new form (which may be slang) spreads, the change is in progress. If it eventually displaces the old form, the change has gone to completion. One area of vocabulary where this is very easy to see is in the slang words used by young people to mean 'really good' in BE. This could be termed as 'cool' 'wicked'. Such words often spread if they have been invented by a popular group such as musicians of popular music. It may survive or be taken over by the next, new word for 'really good' (Mcgregor 2009)

Akmajian, Demers, Farmer and Harnish (2008) observe that slang is something that everyone can recognize but no one can define. Speakers show enormous creativity in their use of slang. Although a precise definition of slang seems extremely difficult, there are however some salient features of this form of language. Firstly, it is a part of casual, informal style of language use. Furthermore, the term slang has traditionally carried a negative connotation and it is perceived as 'being low' and 'vulgar' form of language and is deemed to be out of place informal styles of language.

Secondly, slang like fashion in clothing and popular music, changes quite rapidly and like fashion the fall out is in a matter of years or even months. According to Millar (2007) this rate of turnover is much greater than other areas of the vocabulary of language. People like to change their speech in much the same way they change their hemlines or neckties. This is particularly noticeable among teenagers for who last year's clothes and hairstyles can be embarrassing in the same way last year's speech can also be embarrassing. This awareness is vital since the alternative may be social ostracism.

Akmajian et al (2008) observe that specific areas of slang are often associated with a particular social group and hence one can speak of teenage slang, underworld (criminal) slang, the slang of the drug culture and so on. In this respect, slang is a kind of jargon, and its use serves as a mark of membership and solidarity within a given social group. To use out-dated slang or to use current slang inappropriately is to be hopelessly 'out of date' and to be excluded from an "ingroup".

Slang is sometimes referred to as vernacular(especially when it is associated with a particular social group) and some forms of slang fall under the term colloquialism referring to informal conversational styles of language. These terms however do not carry a negative connotation. Akmajian et al (2008:304) compile slang expressions used by American college students.

\section{Word}

2a)Hangin

b) Hotty

c) Lamo

d) Phat

e) Peeps

\author{
Gloss \\ 'to relax' \\ 'physically attractive person' \\ 'weird person' \\ 'good, cool, neat' \\ 'parents'
}

Slang vocabulary often consists of regular vocabulary used in specific ways. For example the words turkey and banana are regular vocabulary items in English and can be used in formal styles with their literal meaning. But in slang they can be used as insults (referring to stupid or foolish people).

3a) He's such a turkey

b) She has gone bananas

(Akmajian et al 2008:304)

It also consists of words from regular word formation devices used to create new words. For example, slang words can be coined, as was the case for forms such as diddleysquat. He doesn't know diddleysquat- 'He doesn't know anything'. Akamajian et al (2008:305) observe an interesting phenomena in American slang where a suffix -city or -ville is used to create various compound expressions which roughly translate to expressions of maximum concentration or extreme degree.

4a) She cried all night... you know, heartbreak city

b) That guy's really strange - totally weirds-ville.

c) What a boring place-talk about nowhere ville.

d) We're in fat city

e) What a bummer! It is, like, bug city.

Slang use is also of social variation and includes factors of age, ethnicity and even religion. Different generations of speakers often show difference in speech, for instance in use of slang terms such as buck 'dollar' 'wicked' 'good' cool 'good, up to date'. Some slang terms such as buck, dwindle (of Shakespeare's time) end up as standard lexemes. Many on the other hand do not survive for long and their use can be characteristic of a particular generation group, the youth of a certain time. A common characteristic of secret registers (which are confined to certain groups) is that in these registers is the replacement of a lexeme by a lexeme opposite in the meaning or nearly opposite in meaning, commonly expressed in slangs as in wicked and sick for 'good'. 
Sometimes these changes go hand-in-hand with semantic changes. Semantic changes are not as regular as sound change and are frequently restricted to individual lexemes. Some lexemes develop a pejorative meaning over time: for example silly which from old English meant 'happy, blessed, blissful' and took on the meaning 'humble, simple' then 'feeble, weak' in middle English but is now 'weak-minded and stupid' in modern English. The reverse process known as amelioration is seen in a word like 'knight' which from old English meant 'boy' then shifted to 'servant' in middle English and is now 'a member of noble nobility' (Mcgregor 2009).

Millar (2007) says language change is inevitable. This change is neither in the language resulting in immediate improved communication or as critics often maintain, that most changes represent nothing more than 'sloppiness' or 'corruption'. If the spectacular collection of changes which English has undergone in the last thousand years or so were really mostly 'corruptions' of an originally unsullied tongue, then modern English would be so debased that we would hardly be able to use it at all.

Language change according to Millar (2007) therefore is best observed in the difference between spoken and written French. The French Academy set up to maintain the proper use of the French language has failed to keep up with spoken French. Millar (2007:12) cites George (1993) who gives examples of contemporary French spoken mostly by young people.

5a) 'These clothes are very expensive

Written: Ces vêtements coûtent très chers

Spoken: Cesfringuescoûtent la peau des fesses

b)My brother is very good at arithmetics

Written: Mon frère est très fort en arithmétique.

Spoken: Le frangin, ilestgiga fort en cunu.

c) 'There's the woman whose bag was stolen'

Written: Voila la femme a qui on a volé le sac

Spoken: Vla la meuf qui s'est fait péta son keus

Millar (2007) goes on to postulate that a French speaker learning English for example must learn to say "bloody car won't start' and not "I fear our motor car is declining to start". Changes in language therefore are often brought about first through speech acts. Apart from fashion, change in language is also brought about by borrowing which can be done for necessity where an original word in the language doing the borrowing does not have that word. For instance, technological words which are often maintained into but the sound of the language may be placed on it following the ordinary phonological patterns of the borrowing language. Borrowing may also be done for prestige as the borrowing did by English for French words, even though they had their own words which were replaced by French words (Millar 2007).

\section{The Linguistic Map of Cross River University of Technology (CRUTECH).}

CRUTECH is situated in the Cross River State capital, Calabar. The university is a microcosm of the state as students from all 18 Local Government Areas converge on the University for their Higher Studies. The Cross River State itself is situated within the South South geo-political zone of Nigeria. Other students come from neighbouring states within the zone from states such as Akwa-ibom, Bayelsa, Delta, Rivers and Edo. From the South-East states students come from states such as Abia, Imo and Ebonyi states. Others come from as far off as Lagos-some of which may be indigenous to Cross River but reside in Lagos. And yet there is a sprinkling of Yoruba students from the South West states including Ekiti, Oyo, Ondo etc. The student body could therefore be said to be mostly from Southern Nigeria.

\subsection{The indigenous languages spoken by the students}

From such a wide area, a melee of languages is being spoken on the campus. These include students' indigenous languages which from the South-South geopolitical zone include a wide variety as this is where the majority of Nigeria's minority languages are spoken. In Cross River State we have languages such as Efik, Bekwarra and Ejagham which are the three state languages. Others are Lokaa, Leggbo, Yala, Bokyi, Mbembe, Mbube. Yet others include clusters such as the Agwagune cluster, the Bette cluster etc. There are roughly 37 languages and a network of dialects in Cross River State (Udoh 2003). Two major sub groups exist in the North of the State-Bendi and Upper Cross all of which belong to the Benue-Congo family following Crozier/Blench (1992) classification. The lower Cross speakers in the state include Efik, Ito and Ukwa. The Upper-Cross sub group is the largest covering several LGAs from Obubra LGA to Biase LGA which include four LGAs. Other sub groups include Idomoid and Bantoid sub-groups, spoken further north in the state from Ikom LGA to Obudu LGA.

From neighbouring Akwa-Ibom state,Essien (1990), Urua (2000), all endorse the umbrella term Ibibiod for a variety of cluster of languages which are of the Lower Cross group and which share a common history and are all genetically related. There is a high level of mutual intelligibility among the speech groups in the Lower Cross language group. Akwa-Ibom state is made up of 21 varieties of the Lower Cross Group of languages with the most marked variety being Obolo which is also spoken in Rivers State (Crozier \& Blench 1992). 
In other South-South States, Ijaw is spoken throughout Bayelsa State with pockets of Edo Group in the State. The Ijoidgroup are divided into Izon, Nembe-Akaha and Inland Ijo clusters while Edoid languages are made up of Southern Edoid, Delta Edoid and Central Edoid (Efere\& Williamson 1999:95-107). Therefore, inspite of the dominance of Ijo, the state is a linguistically heterogenous state (Akpo 2003). The Ijo language cuts across the five states of Rivers, Delta, Edo, Bayelsa and Ondo States, but Bayelsa has the widest varieties.

Obih (2003) cites four linguistic representations in Delta State. Each of these has varieties with some having more diversity than others. The Edoid group includes Urhobo and Isoko among others. The Ijoid is spoken in Bomadi, Burutu and Patani LGAs. The Igboid has Ika as the variety represented in Delta and is spoken in roughly 9 LGAs. Delta is also a heterogenous State.

Although Edo (Bini) is the dominant language spoken in Edo State it has several varieties including the Ishan group of varieties, Urhobo and Isoko dialects. There is more diversity in the northern part of the state which includes Edoid, Ijoid, Yoruboid and Igboid (Ibifake 2003).

Rivers State has 23 LGAs, 12 ethnic groups and 6 major linguistic sub-groups have been classified. These include Ijoid, Lower Niger (Igboid), Ogoni, Central Delta, Delta-Edoid and Lower Cross. None can be regarded as the dominant language. However, the larger language communities are Izon (Ijo group) Ikwerre (Lower Niger group) Khana and Gokana (Ogoni group) (Udofia 2003).

The Yoruba language belongs to the yoruboid group with variations which are dialects. It is one of Nigeria's 3 major languages. It is spoken widely in the South-West comprising seven states including Lagos state.

\subsection{The English language}

This is spoken widely in the university campus by all students. Passing the English language examination at the West African school Certificate level WASC or ' $\mathrm{O}$ ' level and passing it at the university entrance examination, the Joint Admissions and Matriculation Board (JAMB) exam is a prerequisite for entering the University to do any undergraduate studies.

The English language is Nigeria's official language, it is also the language used in all important spheres of the society. It is used formally in administration, in education it is the language of instruction, in business, in religion, in the media and in many social activities. The English language enjoys institutional support. Students therefore have no choice but to be proficient in the English language and so it is used in their studies and in general interaction.

\subsection{The Nigerian Pidgin (NP)}

The Pidgin, according to Todd (1978) is essentially a communication system that develops among people who do not share a common language. It is also viewed as a self-imposed language that cuts across ethnic, cultural political and psychological barriers (Ejele 2003). NP came about as a result of language contact since it is a product of urbanization (Mafemi 1972). In spite of the fact that English is the official institutionalized language of the university, the NP thrives as a more acceptable language of communication among the student population. Its acceptability in the university is further enhanced by the heterogeneous nature of the campus's sociolinguistic space which is basically a reflection of what exists in the wider national sociolinguistic space. The Nigerian pidgin is particularly influenced not just by English (the superstrate) but by local languages too (the substrates). According to Mafeni (1972) NP is made up of 70\% English words and 30\% local languages as a result of language contact. Elugbe (1995:286) sees this combination as "the vocabulary of the NP is English while its grammar is Nigerian. Ejele (2003), observes that students and lecturers alike speak NP.Okon (2003) observes that NP dominates the speech patterns of undergraduates in tertiary institutions and that they speak better NP than English.

Okon (2003) observes that the NP is a language accepted and recognized by all Nigerians at all levels of education and class as an effective language of communication and serves in many functions such as in the media for news broadcasts, current affairs, advertisement, socio-political and economic discussions and activities. NP is used in almost all state radios as Elugbe and Omamor (1991:148) observe that "any broadcast in NP would reach more people than English, Hausa, Yoruba and Igbo singly".

\section{Theoretical Framework and Methodology}

This work is based on the theory of speech accommodation. According to Mcgregor (2009) speech accommodation is a way of reducing the social distance between the interlocutors. Crystal (2003) says the accommodation theory aims to explain why people modify their style of speaking (accommodate) to become more like or less like that of their addressee(s). For example, among the reason why people converge towards speech patterns of their listener are the desires to identify more closely with the listener, to win social approval or simply to increase the communicative efficiency of the interaction.

There is the application of the accommodation theory and speech convergence as the students tend to lean towards sounding the same way not just in use of words but also in pronunciation. Their speech therefore converges towards the speech of their fellow students. There is therefore speech accommodation, brought about by their interactions, associating often at different levels - clubs, sports, at the department, in the hostel etc. This accommodation and convergence is played out in the use of slang language among the students. Most of these slang expressions are derived from different sources as will be seen in our discussion. However, most of the slang expressions are also expressed in Nigerian Pidgin, a restricted code, which according to the British sociolinguist Basil Bernstein as cited by Singleton (2000:113) is the code of intimacy. The situation in the university campus clearly calls for restricted code of intimacy 
among the students who share so many experiences in the same environment and this bond is further cemented by using NP which is a language of intimacy among them in spite of the official language English or their individual indigenous languages. This intimacy is further reflected in slang usage which serves as a 'code' and can exclude the situation of formal learning and the elaborate code of standard English (SE) in more formal situations.

Data for this study were obtained primarily through "naturally occurring casual speech" (Kadenge and Mavunga 2010) from informal groups on the campus. We also employed participant observation in very casual and naturalistic settings. Although the interactions were naturalistic and casual, a total controlled number of 100 students were involved in the study. Interactions were limited to undergraduate students in the Calabar campus. They included 60 male and 40 female students. This fell within the ratio of the student population. However, within the faculties there were more female students in the study from the faculties of Education and Communication technology. Students fell within the age range of 16 to 22 years, from 100 level to 400 level in their respective departments. Students were selected from five Faculties of Science, Engineering, Education, Communication Technology and Environmental Studies.

\section{Discussion and Analysis}

Among Nigerian youths generally and those from the south-south geo-political zone in particular there is a clear gradual language shift from the indigenous language to NP and Nigerian English (NE) among their peers. Within these usages the NP is highly favoured and there is an intense use of slangs from the NP which is developing into standard vocabulary for the youths. According to Holmes (2008) this usage also serves as a form of acceptability among peers, being able to speak the appropriate language. It all comes down to domain and some specific social factors in order to determine a code choice. The social distance among the youths does not apply as they all fall within the same social distance irrespective of whether they are friends, strangers or even siblings. The use of slang particularly NP slangs are a way of social bonding. Slang forms therefore act as solidarity markers for these youths, as if they were in the same social class, (Singleton 2000). Slang is an area of vocabulary which reflects a person's age, (Holmes 2008). Slang therefore introduces new vocabulary or forms of words. This is what was discovered among the students of CRUTECH campus, Calabar, as we examine the language and origins of these slang usage.

\subsection{Multilingualism, Code-switching and Code-mixing in CRUTECH}

Students on CRUTECH campus, as mentioned earlier, come from mostly the southern half of Nigeria. This includes Lagos and Delta state which are the hot beds of new vocabulary into NP usage. Lagos has an influential status on NP usage. It is the meeting point for people of diverse socio-cultural and educational backgrounds. Given these differences, NP serves as the most suitable bridge for the people's communication gap. (Abdullahi-Idiagbon;2007). However, other languages are used in the campus and this is highly reflected inconstant code-switching and code-mixing

The major factors that crop up in a multilingual campus like CRUTECH are those of code-switching and code-mixing. According to Hudson (2001) anyone who speaks more than one language chooses between them according to circumstances. The first consideration is which one will be comprehensible to the person he addresses. In a multilingual community such as CRUTECH, different languages are always used in different circumstances and the choice is always controlled by social rules. In CRUTECH the different codes are used as follows: SE for lectures, within and outside the classroom with those in authority, in offices to see to the everyday running of one's affairs. The student however switches code to NP when speaking to his fellow students particularly his peers in his level. If he is not familiar with a particular student, he speaks to him in SE and if he discovers within the course of the interaction that the other person is from his linguistic community, he switches to his language (MT/LI).

Within a day the student may have used at least four codes including NP, NE, SE and MT/LI.

He addresses his lecturer in class

6a) Sir, is there a deadline for the assignment?

At the bursary department he encounters an unknown fellow student who is rather slow on the queue.

b) Why don't you just hand in your teller? We are all running late.

As he gets frustrated, he switches to NP

c) Bros, abeg do quick, man get to comot here

'Brother, please hurry. One needs to get out of here'.

On leaving the bursary, he runs into his friend and classmate and hails him

d) Hey, badoo! How far? You just land?

'Hey how are you? You just got here?'

Badoo is a slang word from baddest, also a slang word which has the opposite meaning of best. It is mostly used by yahoo boys to hail one who has fooled a maga. According to Ugot (2009:234) maga is someone who has been fooled into parting with his money.

On getting back to the hostel where he shares a room with someone from his linguistic community, he switches to his MT/LI (Agwagune, a language spoken in Biase Local Government area of Cross River State), to complain of hunger.

7e) Mómérézìbànì

'I'm hungry' 
These are all situational code switching because the switching coincides with changes from one external situation to another. We have a case of code-mixing which is also very common on campus. This is a linguistic cocktail and could be a balance of two or more languages used all at once. In (8a) we have a case of one student yelling instructions to a fellow student.

8a) Hey bros! Abeg help me carry that bag. Be careful O! I have some delicate things there. Wetin naa? how you dey jack am so?!

'Hey brother! Please help me carry that bag. Be careful, I have some delicate things there. What's this? Why are you lifting it up roughly?'

He starts with NP then SE, then back to NP. Note that the expression 'o' is inserted where we have SE usage. This immediately puts an NE slant to it as this expression is common in NP and NE usage.

9a) Yes o!

b) Sorry o!

c) Na wa o!

Where ' $o$ ' could mean anything from a plea as used in (8a) to an emphatic reply as in (9a), a commiseration as in (9b) or a surprise as in $(9 \mathrm{c})$ etc. Such code-mixing could be found strictly in one sentence.

10a)Chineke God, see you, na so so chop chop you sabi, nànásì?

$$
\text { Igbo SE NE NP AGWAGUNE }
$$

'God, look at you, you only know how to eat, don't you?!'

In (10a) the speaker starts with Igbo and veers into NE then NP and ends up with Agwagune his MT/LI. The word God in Igbo also repeated in English is a common expression normally used in NP. In (10b) the speaker chastises another student who is being a nuisance.

10b) Joo, comot for road. Haba, I tire for you.

'Please get out of the way. I am tired of you.

Expressions such as joo and haba are Yoruba and Hausa respectively where joois 'please' and haba is simply an expression of surprise, frustration and sometimes disbelief depending on the context.

\subsection{Slang Usage from the Genre of music}

Lagos is the state with the highest number of musicians. The influence of musicians, in spreading slangs among the youths is over-whelming and some of these NP slangs have been incorporated from the Yoruba language as Lagos is the most influential in the Yoruba speaking south west geo-political zone. This, in a nutshell, accounts for a considerable number of Yoruba words and slangs found in the NP, coming from music in particular and other usages. Lagos influence therefore affects the use of NP slang on most Nigerian campuses and CRUTECH as well. Let us look at some NP slangs in use from current Nigerian popular music and some Yoruba words incorporated there in.

Ugot (2009) points out that NP features prominently in contemporary Nigerian music with new words coined and adopted into the lexicon of NP. Nigeria also churns out a number of artists in popular music and this has helped to swell the lexicon of NP. Let us examine some of the slang expressions used by CRUTECH students.

\section{Expression}

11a) Oluwa is involved

b)Berry pondise

c)Kush

d) SK/Street king/Skunk

e) Blau

f)Long tin

g) Omobabalawo

\section{Gloss}

'God is there'

'On that"

'Indian hemp'

'Indian hemp, marijuana'

'to smoke Indian hemp'

'No problem'

"boss" Literally 'child of medicine man'

(11a) and (11b) are both taken from songs by the musician wizkid. The expression in (11a) is used in reply to questions relating to one's health or examinations. Oluwa is Yoruba for 'God'. (11c), (11d) and (11e) are lifted from American rap music into NP lexicon. Also from the genre of music and reflecting Nigeria's multilingualism from the Local community of Calabar and its environ comes the following

\section{Word}

12a) Etighi

b) Kukere

c) Mfunalbagha

\section{Gloss}

'Literally 'Okra',

'Do not worry'

'No problem'

(12a) and (12b) are names of a dance and song respectively. (12c) is also from a popular musician, Tuface, and is Ibibio spoken in neighbouring Akwa-Ibom State. 


\subsection{Slang expressions from Lagos and Delta States}

From Lagos, words in the NP slang lexicon used by students include

\section{Word}

13a) No lele

b) Carry go

c) Chassis

d) No dulling/No sleeping on the bicycle

e) Shekpe

f) Notin spoil

g) Notin do you

h) Your fada

I) No be beans

\section{Gloss}

'No problem'

'Go ahead'

'It's okay, correct'

'Be sharp, lively'

'Alcohol'

'No problem'

'You're alright'

'You are not serious'

'It's not easy'

In (13h) this expression is used especially if the other person is perceived to be telling a lie in an argument. The expression was once highly offensive but has since evolved from a serious abuse of one's father to a light hearted reprimand.

Warri NP which is also from Delta State, is very strong in NP general usage. This is because the NP in Warri is practically creolized (Mafeni 1972). The Warri variety is spoken by a large number of people in southern Nigeria. It is also highly productive in supplying new vocabulary to the NP lexicon. Here are some examples of NP slang of the Warri variety spoken on the camps.

\section{Word}

14a) Yawa

b) Kolo

c) Yawa dongas

d) Kasala

e) Kasala don burst

f) Form

g) Chicala

h) Tank

i) Butty

j) Carry shoulda/ Show bodi

k) Nakakpako

1) Tomashanko

\section{Gloss}

'Trouble/problem'

'Mentally deranged'

'There's trouble brewing'

'Trouble, problem'

'There's trouble'

'Pose'

'Girlfriend'

'Drink'

'From Ajebota 'A rich kid', literally “one who eats butter"

'proud'

'have sex'

'locally brewed gin'

\subsection{Slang usage from campus cults and societies}

Not all slang in NP derives their source from the Lagos influence. Some slangs are exclusively used by cliques of students who belong to particular cults or societies, although the expressions used openly finally find their way into the general students vocabulary. Some of the vocabulary are therefore highly technical and can only be understood by those "who belong", the associates or initiated. Slang in this perspective normally generates negative impressions from the non-aligned students and other members of the campus community. Such expressions are hardly used by the general student body. However, others have gained currency into the vocabulary and include

\section{Expression}

15a) Wetin be your logo?

b) The guy don gaz

c) Shine your eye well well

d) Chill

e) Fashy de guy

\section{Gloss}

'Identify yourself, who are you?'

'The man is dead'

'Be vigilant/careful/observant'

'Be calm"

'Ignore the man/lady'

These are expressions that are now common usage and (11c) in particular is now in use not just by the youths all over Nigeria but by adults as well and has been used in an advert by The National Agency for Food and Drug Administration and Control, (NAFDAC) a Nigerian government agency that raises awareness on fake drugs.

\section{Expression}

16a) Jazz down

b) Bloody civilians

\section{Gloss}

'Kneel down'

'Non cultist' This is an expression from the military era in Nigeria. 

c) On the high sea
'Not around'
d) Typhoon blasted sailor
'Someone in a high position'

The core register of the initiated was difficult to come by, as students were not willing to openly admit being in the cult.

\subsection{Slang Usage from the Language of Technology}

Students make up slangs from the language of technology and these are very current among the student population. They are mostly to do with the use of the computer and include

\section{Expression}

17a) Abeg delete yourself

b) Why your brain no dey boot?

c) Men, I don shut down for the day

d) Abeg, $\log$ in

e) Log out

\subsection{The Creative versatility of NP slang}

\section{Gloss}

'Please leave here'

'You are not using your brain'

'I'm done for the day'

'Please join me' (usually used to invite someone to eat)

'Stop talking' (from an argument)

It is observed that there may be several slang words or expressions with the same meaning. Sometimes they may be coming from different sources as in all the expression for 'no problem'. See (11f, 13a, 13f) or the students' versatility in borrowing words for marijuana/indian hemp as in (11c) (11d) (11e). The students' versatility is also reflected in the number of greetings depicting practically the same sense.

18a) Which level?

b) Wa gwan?

c) Wetin de sup?

d) Waz up?

All practically mean 'what's happening?/What's going on?'

While

e) How far?

f) How you dey?

g) How now?

Are all greetings of 'How are you?'

h) Badoo!

i) Hey Bros!

j) Hey, my guy!

Are all ways of just hailing a friend.

\section{Conclusion}

On the positive side, slang usage in NP has helped to build up the vocabulary of the language in that some do manage to slip past the slang stage and are accepted into current usage. This has been the case of many words and expressions prior to this. However, it is believed that the majority of these words and expressions will die out as the next crop of youths /students who fall within the age group that use new slang words come up with their own forms.

Unfortunately, many of the youths / students tend to forget that this is not standard English and sometimes use these slang expressions in their everyday studies and communication. Therefore, using it as if it were standard English in studies is highly detrimental. Again there are those who argue that constant use of NP is also detrimental to one's capacity to speak 'good' English. We agree with Wardhaugh (1986:55) who asserts that pidgin is not a 'bad' variety of a language but has its own legitimacy, that is, its own history, structure and array of functions.

The versatility of students and youths in general in coming up with innovative expressions to introduce into the NP lexicon is nothing short of amazing. This vibrancy in the language is due to the ability to find new forms to suit daily needs in language use. We have also witnessed the origin of some of these new expressions that all come in as slang expressions. There is a need however for students to maintain their situational code-switching so that they can discern when it is appropriate to use a particular code.

It is now up to Linguists to be able to know the difference between slang expressions and non-slang in the process of codification and standardization of the NP. 


\section{References}

Abdullahi-Idiagbon, M.S. (2007). The sociolinguistics of Nigerian Pidgin (English) on university campuses. In D. Adeyanju (ed) Sociolinguistics in the Nigerian context. Pp 201-218. Ile-Ife: Obafemi Awolowo press

Adeyanju, D. (2007). Slang usage in educated Nigerian English: A sociolinguistic overview. In D Adeyanju (ed) Sociolinguistics in the Nigerian context. Pp 265-277. Ile-Ife: Obafemi Awolowo press

Akmajian. A. Demers, R. A. Farmer, A. R \& Harnish R. M (2008) Linguistics: An introduction to language and communication. New Delhi: Prentice Hall of India.

Akpo. R. (2003). Bayelsa State. In I.I. Udoh (ed) The languages of the south south zone of Nigeria; A geo-political Profile Pp40-50. Lagos: Concept publications.

Crozier, D. H. \& Blench R. M. (1992). An index of Nigerian languages. Dallas: Summer Institute of Linguistics

Crystal, D. (2003). A dictionary of linguistics and phonetics. Oxford: Blackwell Publishing

Efere, E. E. \& Williamson, K. (1999). Languages: In E. J. Alagoa (ed) The land and people of Bayelsa State: Central Niger-Delta Pp 95-107. Port Harcourt: Onyoma Research Publications

Ejele, P.E. (2003). Language use in a multilingual society: An update on the Nigerian situation. In O. Essien \& M. Okon (eds) Topical issues in sociolinguistics. The Nigerian perspective. Pp 111-113. Aba: National Institute for Nigerian Languages (NINLA).

Elugbe, B.(1995). Nigerian pidgin: Problems and prospects. In A. Bamgbose \& A. Thomas (eds) New Englishes: A West African perspective. Pp284-299. Ibadan: Mosuro (British Council).

Essien, O. E. (1990). A grammar of the Ibibio Language. Ibadan: University Press Limited

Holmes, J. (2008). An introduction to sociolinguistics. Essex: Pearson Education Limited

Hudson, R. A (2001). Sociolinguistics. Cambridge: Cambridge University Press.

Kadenge, M. \& Mavunga, G. (2010). Shona metaphors created during the Zimbabwe crisis: A cognitive grammar analysis Linguist Atlantica 31, 1-21

Mafeni, B. (1972). Nigerian Pidgin. In J. Spencer (ed) The English language in West Africa. Pp London: Longman Books Limited.

Mcgregor, W. B. (2009). Linguistics: An introduction. London: Continuum International Publishing Group.

Millar, R. M. (ed) (2007) Trask's historical linguistics. London: Hodder Education.

Okon, B. (2003) Communication and social perception of the Nigerian Pidgin in Cross River State. In O. Essien and M. Okon (eds) Topical issues in sociolinguistics: The Nigerian perspective .Pp 403-417. Aba: National Institute for Nigerian Languages (NINLA).

Singleton, D. (2000) Language and the lexicon: An introduction. London: Oxford University Press.

Todd, L. (1984) Modern Englishes: Pidgins and Creoles. Oxford: Basil Blackwell Inc.

Udoh, I.I .(2003) The Languages of the Cross River State of Nigeria. Uyo journal of humanities. 8. 87-109.

Ugot, M (2009) Lexical pidgin innovations in contemporary Nigerian popular music. Oniong: A contemporary journal of interdisciplinary studies. I (I) 225-238

Urua, E.E. (2000) Ibibio phonetics and phonology. Cape Town: Center for Advanced Studies of African Society.

Wardhaugh, R. (1986) An introduction to sociolinguistics. Oxford: Basil Blackwell Inc. 